\title{
The correct identity of Lasiosiphon microphyllus (Meisn.) Meisn. (Thymelaeaceae) and the new combination Lasiosiphon kuntzei (Gilg.) R.Kolokoto \& Magee
}

\begin{tabular}{|c|c|}
\hline \multicolumn{2}{|c|}{$\begin{array}{l}\text { Authors: } \\
\text { Refilwe Kolokoto }{ }^{1,2} \text { @ } \\
\text { James S. Boatwright }{ }^{1} \text { (1) } \\
\text { John C. Manning }{ }^{2,3} \text { ( } \\
\text { Lize von Staden } \\
\text { Anthony R. Magee }\end{array}$} \\
\hline \multicolumn{2}{|c|}{$\begin{array}{l}\text { Affiliations: } \\
{ }^{1} \text { Department of Biodiversity } \\
\text { and Conservation Biology, } \\
\text { University of the Western } \\
\text { Cape, Cape Town, } \\
\text { South Africa }\end{array}$} \\
\hline \multicolumn{2}{|c|}{$\begin{array}{l}{ }^{2} \text { Compton Herbarium, } \\
\text { South African National } \\
\text { Biodiversity Institute, } \\
\text { Cape Town, South Africa }\end{array}$} \\
\hline \multicolumn{2}{|c|}{$\begin{array}{l}{ }^{3} \text { Research Centre for Plant } \\
\text { Growth and Development, } \\
\text { University of KwaZulu-Natal, } \\
\text { Pietermaritzburg, } \\
\text { South Africa }\end{array}$} \\
\hline \multicolumn{2}{|c|}{$\begin{array}{l}{ }^{4} \text { Threatened Species } \\
\text { Programme, South Africa } \\
\text { National Biodiversity Institute, } \\
\text { Pretoria, South Africa }\end{array}$} \\
\hline \multicolumn{2}{|c|}{$\begin{array}{l}{ }^{5} \text { Department of Botany and } \\
\text { Plant Biotechnology, } \\
\text { University of Johannesburg, } \\
\text { Johannesburg, South Africa }\end{array}$} \\
\hline \multicolumn{2}{|c|}{$\begin{array}{l}\text { Corresponding author: } \\
\text { Anthony Magee, } \\
\text { a.magee@sanbi.org.za }\end{array}$} \\
\hline $\begin{array}{l}\text { Dates } \\
\text { Received: } 19 \\
\text { Accepted: } 13 \\
\text { Published: } 19\end{array}$ & $\begin{array}{l}\text { une } 2018 \\
\text { Eeb. } 2019 \\
\text { Aug. } 2019\end{array}$ \\
\hline Read online: & \\
\hline 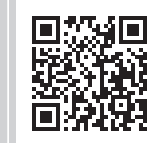 & $\begin{array}{l}\text { Scan this QR } \\
\text { code with your } \\
\text { smart phone or } \\
\text { mobile device } \\
\text { to read online. }\end{array}$ \\
\hline
\end{tabular}

Authors:

Refilwe Kolokoto ${ }^{1,2}$

James S. Boatwright ${ }^{1}$

John C. Manning ${ }^{2,3}$

Affiliations:

Cape, Cape Town,

South African Nation

Biodiversity Institute,

${ }^{3}$ Research Centre for Plant Growth and Development, University of KwaZulu-Natal, Pietermaritzburg

${ }^{4}$ Threatened Species National Biodiversity Institute,

${ }^{5}$ Department of Botany and Plant Biotechnology,

Corresponding author:

Anthony Magee,

Dates

Received: 19 June 2018

Accepted: 13 Feb. 2019

Published: 19 Aug. 2019
Background: While working towards a taxonomic revision of the genus Lasiosiphon (Thymelaeaceae), it became clear that the current application of the name Lasiosiphon microphyllus did not correspond to the identity of the type material.

Objectives: To effect the requisite nomenclatural changes.

Method: Herbarium specimens from NBG and PRE as well as the type collections of L. microphyllus and Lasiosiphon suavissimus were studied.

Results: Nomenclatural corrections are required for the taxa currently treated as L. microphyllus and L. suavissimus.

Conclusions: Lasiosiphon microphyllus is recognised as the earliest name for the tetramerous species currently known as L. suavissimus. Gnidia kuntzei is the earliest available name for the pentamerous taxon currently treated as L. microphyllus and the new combination Lasiosiphon kuntzei (Gilg.) R.Kolokoto \& Magee is provided.

Keywords: new combination; Gnidia microphylla; Gnidia suavissima; Gnidia kuntzei; Greater Cape Floristic Region; Karoo; Richtersveld; new synonym.

\section{Introduction}

Lasiosiphon Fresen. (Thymelaeaceae) is a genus of subshrubs, shrubs or small trees from Africa and Madagascar (Wright 1915). Lasiosiphon was only recently resurrected from the large, polyphyletic genus Gnidia L., largely based on the phylogenetic analyses of Beaumont et al. (2009) (Magee \& Manning 2017; Manning \& Boatwright 2013), and the taxonomy of the species is still unclear. The genus has its centre of diversity in southern Africa, with approximately 29 species currently recorded from the region (Magee \& Manning 2017). Madagascar is also rich in Lasiosiphon species (Boatwright et al. 2017), with 13 recognised in the taxonomic revision of Rogers (2009). However, the number of species in tropical Africa remains unclear, with all of the species still placed within Gnidia.

During the study for a taxonomic revision of the genus Lasiosiphon, nomenclatural issues were encountered around Lasiosiphon microphyllus (Meisn.) Meisn. This species was described as Gnidia microphylla Meisn. (1841), based on a collection made by J.F. Drège (1794-1881) near the mouth of the Orange River in Northern Cape, South Africa. Although Meisner (1841) described the species as tetramerous, he later (Meisner 1857) transferred it to the otherwise pentamerous genus Lasiosiphon, and expanded its circumscription to include pentamerous specimens from the Karoo region of South Africa. Our review of the application of these names has led us to question this decision.

\section{Materials and methods}

Herbarium specimens were examined from BOL, NBG, PRE and SAM (acronyms following Thiers 2017), the primary holdings of southern African flora. These were compared with images of type specimens on JSTOR Global Plants (https://plants.jstor.org) and the NY Herbarium (http://sweetgum.nybg.org/science/vh/).

How to cite this article: Kolokoto, R., Boatwright, J.S., Manning, J.C., Von Staden, L. \& Magee, A.R., 2019, 'The correct identity of Lasiosiphon microphyllus (Meisn.) Meisn. (Thymelaeaceae) and the new combination Lasiosiphon kuntzei (Gilg.) R.Kolokoto \& Magee', Bothalia 49(1), a2383. https://doi.org/10.4102/abc.v49i1.2383

Copyright: @ 2019 . The Authors. Licensee: AOSIS. This work is licensed under the Creative Commons Attribution License. 


\section{Results}

The name L. microphyllus is currently applied to a taxon that is widely distributed across the dry interior of South Africa (Bredenkamp 2013; Meisner 1857; Retief \& Meyer 2017; Wright 1915). However, the type specimen collected by J.F. Drège (Drège 2976a) is from the Richtersveld near the northwestern border of South Africa (Figure 1). The type differs significantly from collections from interior South Africa in its glabrous, \pm membranous involucral bracts and in its tetramerous flowers with a shorter, glabrous hypanthium \pm $5 \mathrm{~mm}$ long. In contrast, populations from interior South Africa have puberulous, papery involucral bracts and pentamerous flowers with a longer, hairy hypanthium \pm $10.5 \mathrm{~mm}$ long. The current application of L. microphyllus to the pentamerous taxon from the interior is obviously incorrect, and the name should be restricted to populations from the northwest coast matching the type. These populations are currently known under the name Lasiosiphon suavissimus (Dinter) Domke. (Figure 1), described from southern Namibia. Examination of the type of L. suavissimus confirms that it corresponds closely with the type of L. microphyllus, and we regard the two as representing the same taxon. As L. microphyllus is the earlier name, we apply it here to the tetramerous taxon from the Richtersveld and southern Namibia, reducing L. suavissimus into synonymy.

The pentamerous taxon from the South African interior is, therefore, currently without a name. Wright (1915) treated Gnidia kuntzei Gilg. as a synonym of L. microphyllus. The type specimen of G. kuntzei is pentamerous and was collected near Middelburg (Kuntze s.n.) in the dry interior (Figure 1). It shares all the diagnostic characters with other pentamerous populations from the South African interior currently included in L. microphyllus and is the oldest available name for this taxon. We reinstate it and provide the new combination L. kuntzei (Gilg.) R.Kolokoto \& Magee.

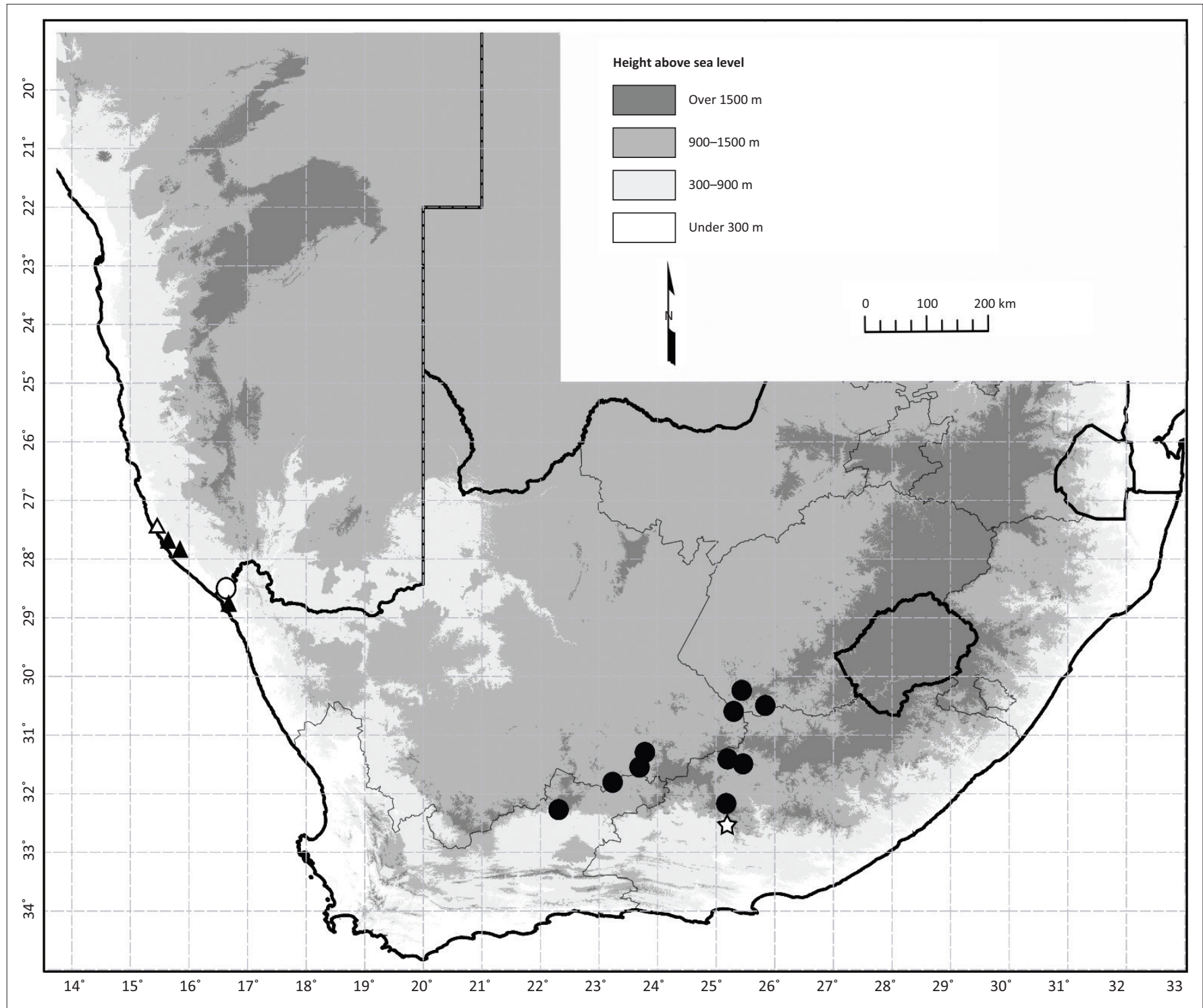

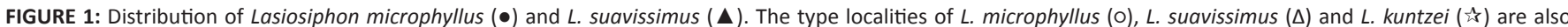
indicated. 
The relevant nomenclatural changes are formalised below:

(1) Lasiosiphon microphyllus (Meisn.) Meisn. in De Candolle, Prodr. 14: 593 (1857). Gnidia microphylla Meisn. in Linnaea 14: 432. (1841). Type: South Africa [Northern Cape], 'in collibus siccis prope Kuigunjels ad fl. Garip, alt. 200 ped.' [dry hills near Kuigunjels, near the mouth of the Orange River, 200 feet], Drège 2976a (NY, holo--image!).

Gnidia suavissima Dinter. in Feddes Repert. Spec. Nov. Regni Veg. 16: 340 (1920), syn. nov. Lasiosiphon suavissimus (Dinter) Domke. in Biblioth. Bot. 111: 91 [in obs.] (1934). Type: Namibia, 'Namaland, Zwischen Angras-Juntas und Buntfeldschuh' [betweenAngras-Juntas and Buntfeldschuh], July 1913, Schäfer 504 (B, holo.-image!).

\section{Additional specimens examined}

NAMIBIA. Iikaras. 2715 (Bogenfels): flache Östlich der Buchuberg (-DD), 28 June 1929, Dinter 6450 (NBG; SAM); Buntfeldschuch (-DC), 7 Sept. 1922, Dinter 3769 (SAM).

SOUTH AFRICA. Northern Cape. 2816 (Oranjemund): southern Richtersveld, Sandveld, S of Groot Derm, ca. 1-30 km S of Alexander Bay (-DA), 12 Sept. 2001 Jurgens 122329 (NBG). Precise locality unknown: sand dunes at Witbank, Little Namaqualand, 6 Oct. 1926, Pillans 5150 (BOL).

(2) Lasiosiphon kuntzei (Gilg.) R.Kolokoto \& Magee, comb. nov. Gnidia kuntzei Gilg. in Kuntze, Revis. Gen. Pl. 3 (3): 280 (1898). Type: South Africa, Eastern Cape, Middelburg Road, Capland, 17 Feb 1894, Kuntze s.n. (NY, holo.image!).

Lasiosiphon microphyllus sensu Meisn. (1857) et mult. auct. pp. excl. type, non Meisn. (1841).

\section{Additional specimens examined}

SOUTH AFRICA. Northern Cape. 3024 (Prieska): De Aar, Diepfontein (-BA), Aug. 1946, Henrici 3999 (PRE); Diepfontein, Aug. 1946, Brueckner 737 (PRE). 3025 (Colesburg): $39 \mathrm{~km}$ South of Petrusville on road to Colesberg via Perdeberg, Farm Matjiesfontein (-BD), 6 Apr. 1981, Herman 610 (PRE); Colesburg, Coleskop (-CA), Oct. 1935, Throne 51946 (SAM). 3123 (Victoria West): Richmond, hillside just N of town along N1, S-slope (-BD), 18 May 2017, Manning 3627 (NBG); Victoria West, Noblesfontein (-CC), Feb. 1931, Thorne s.n. (SAM); Murraysburg-Nelspoort, $1.9 \mathrm{~km} \mathrm{~N}$ of entrance to Farm Towerfontein, (-DC), 19 Apr. 1997, Steiner 3209 (NBG). Western Cape. 3222 (Beaufort West): Karoo National Park outside Beaufort West, Middle plateau above Klipspringer Pass west of Rooiwalle area close to old soil dam (-AD), 6 Dec. 2005, Bester 6086 (NBG; PRE); Karoo Nature Reserve, Zebra Camp (-AD), 19 May 1981, Linger 2014 (PRE); Beaufort West, Karoo National Park, on rocky ridge at Boesmanvalle (-AD), 3 Nov. 1984, Bengis 457 (PRE). Eastern Cape. 3125 (Middelburg): Middelburg (-AC), Devoon s.n. (SAM); Middelburg, 2 miles [3.2 km] N of Grootfontein, Randjieveld around pollentrap (-AC), 18 Feb. 1963, van Zinderen Bakker 1127 (PRE); Middelburg, Maryland, Schoobee, at foot of small range of hills (-AD/BC), Apr. 1944, Thorns s.n. (NBG). 3225 (Somerset East): Farm Waterval, outside Mountain Zebra National Park (-AA), 12 Dec. 2005, Bester 6372 (PRE). Precise locality unknown: Tyson 1486 (SAM); Flanagan 1379 (SAM).

\section{Acknowledgements}

The authors thank the National Research Foundation (NRF) and GreenMatter for their support.

\section{Competing interests}

The authors declare that they have no financial or personal relationships that may have inappropriately influenced them in writing this article.

\section{Authors' contributions}

R.K. is the lead author, A.R.M. helped to resolve the nomenclature and conceptualise the manuscript, and A.R.M., J.S.B, J.C.M and L.V.S. provided significant input to all drafts of the manuscript.

\section{Ethical considerations}

This article followed all ethical standards for research without direct contact with human or animal subjects.

\section{Funding information}

This study was financially supported by the National Research Foundation (NRF) through research funding and GreenMatter through a master's bursary for R.K.

\section{References}

Beaumont, A.J., Edwards, T.J., Manning, J.C., Maurin, O., Rautenbach, M., Motsi, M.O. et al., 2009, 'Gnidia (Thymelaeaceae) is not monophyletic: Taxonomic implications for Thymelaeoideae and a partial new generic taxonomy for Gnidia', Botanical Journal of the Linnean Society 160, 402-417. https://doi.org/10.1111/j.1095-8339.2009.00988.x

Boatwright, J.S., Van Der Bank, M., Magee, A.R. \& Manning, J.C., 2017, 'Transfer of Madagascan species of Gnidia L. to Lasiosiphon Fresen. (Thymelaeaceae: Thymelaeoideae)', South African Journal of Botany 112, 336-337.

Bredenkamp, C.L., 2013, 'Thymelaeaceae', in D.A. Snijman (ed.), Plants of the Greater Cape Floristic Region 4: The Extra Cape flora, Strelitzia 30, pp. 483-485, South Africa National Biodiversity Institute, Pretoria.

Magee, A.R. \& Manning, J.C., 2017, 'Lasiosiphon esterhuyseniae (Thymelaeaceae: Thymelaeoideae), a new species from Northern Cape (South Africa), and the transfer of two additional southern African species to the genus', Kew Bulletin 72, 12. https://doi.org/10.1007/s12225-017-9685-6

Manning, J.C. \& Boatwright, J.S., 2013, 'Lasiosiphon rigidus (Thymelaeaceae), a new species from the Tankwa Karoo and two new combinations in the genus for South Africa', Bothalia 43, 84-88.

Meisner, C.F., 1841, 'Synopsis Thymelaearum, Polygonearum et Begoniarum Africae Australis, imprimus cl. Drège., J.J. lectarum', Linnaea 14, 432.

Meisner, C.F., 1857, 'Ordo CLXVII. Thymelaeaceae', in A.P. De Candolle (ed.), Prodromus Systematis Naturalis Regni Vegetabilis 14, pp. 493-605, Victoris Masson, Paris.

Retief, E. \& Meyer, N.L., 2017, Plants of the Free State: Inventory and identification guide, Strelitzia 30, South Africa National Biodiversity Institute, Pretoria, pp. 808-814.

Rogers, Z.S., 2009, 'A revision of Malagasy Gnidia (Thymelaeaceae, Thymelaeoideae)', Annuals of the Missouri Botanical Garden 96, 324-369. https://doi. org/10.3417/2006114

Thiers, B., 2017, Index Herbariorum: A global directory of public herbaria and associated staff, New York Botanical Garden's Virtual Herbarium, s.l., viewed 04 April 2018, from http://sweetgum.nybg.org/science/ih/

Wright, C.H., 1915, 'Thymelaeaceae', in W.T. Thiselton-Dyer (ed.), Flora capensis 5, pp. 1-80, L. Reeve \& Co., London. 